\title{
Development of the First P-Stereogenic PCP Pincer Ligands, Their Metallation by Palladium and Platinum, and Preliminary Catalysis ${ }^{1}$ )
}

by B. Scott Williams ${ }^{a}$ ), Paulo Dani $\left.{ }^{a}\right)^{2}$ ), Martin Lutz ${ }^{\mathrm{b}}$ ), Anthony L. Spek*b), and Gerard van Koten $\left.^{* a}\right)^{3}$ )

a) Department of Metal-Mediated Synthesis, Debye Institute, Universiteit Utrecht, Padualaan 8, $3584 \mathrm{CH}$, Utrecht, The Netherlands

b) Bijvoet Center for Biomolecular Research, Crystal and Structural Chemistry, Universiteit Utrecht, Padualaan 8, $3584 \mathrm{CH}$, Utrecht, The Netherlands

In memoriam Professor Luigi M. Venanzi for his pioneering work in organometallic chemistry, and in PCPpincer chemistry in particular

The potentially tridentate $\mathrm{P}$-stereogenic $[\mathrm{P} * \mathrm{CP} *]$ ligands $1,3-\{$ bis $[($ tert-butyl $)($ phenyl)phosphino $]$ methyl $\}$ benzene and 1,3-\{bis[(tert-butyl)(phenyl) phosphino]methyl\}-2-bromobenzene have been synthesized as the protected phosphine-borane adducts. Deprotection with a secondary amine affords the free phosphine ligand which can be metallated by $\mathrm{Pd}$ and $\mathrm{Pt}$ with standard metal synthons. Two of the resultant $[\mathrm{P} * \mathrm{CP} *]$ metal complexes have been characterized by X-ray crystallography. The complexes exhibit a $C_{2}$ symmetric environment about the remaining binding site of the square-planar center, with $t$-Bu groups filling two quadrants of the open site. The Pd complexes can be converted by use of a $\mathrm{Ag}$ salt to the analogous aquo complex, which is catalytically active in the aldol condensation of methyl 2-isocyanoacetate and benzaldehyde. Preliminary results and comparisons with previously reported catalysts with more distal C-stereogenicity are presented.

Introduction. - Transition metal complexes of so-called 'pincer ligands' have found wide application in a variety of fields since this ligand type was first reported by Moulton and Shaw in 1976 [1]. The ligands can be abbreviated as '[ECE]' ligands, where $\mathrm{E}$ is the donating heteroatom. A number of early reactivity studies showed that the chemistry of square-planar late-transition-metal pincer complexes of this type is particularly rich ([2] and references therein). Subsequent studies have demonstrated the utility of such complexes in Lewis acid catalysis [2a][3], Heck reactions [4], Kharasch additions [5], catalytic dehydrogenation [6], transfer hydrogenation [7], and investigations of $\mathrm{C}-\mathrm{H}$ and $\mathrm{C}-\mathrm{C}$ oxidative addition reactions ([8] and references in [8a]).

Recently, many efforts have been concentrated upon the immobilization of the catalytic systems upon recoverable supports, such as dendrimers [5c][9], highly symmetric organic frameworks [10], polymers [11], fullerenes [12], and solid supports [13]. Because of these advances in attachment of pincer ligands to recoverable supports, any new modification of the pincer framework or discovery of new patterns of reactivity can be applied in a straightforward manner to a practical catalytic process, in which the catalyst can be easily separated from the reaction medium, and thus the

1) This work was presented in part at OMCOS 11, Taipei, Republic of China, in July 2001.

2) Present Address: Avantium Technologies B. V., P. O. Box 2915, 1000 CX, Amsterdam, The Netherlands.

3) e-mail: g.vankoten@chem.uu.nl. 


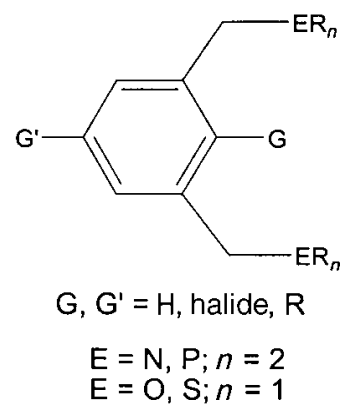

products of the reaction. For this reason, a major focus of the research in our laboratory is the development of the basic chemistry of pincer-supported organometallic catalysts. Despite the wide variety of catalytically active pincer complexes that have been reported, relatively few attempts have been made to explore enantioselective reactions with chiral versions of the pincer system $[14]^{4}$ ). We report herein the synthesis and procedures for the palladation and platination of a new type of [PCP] pincer ligand, as well as some initial results of the use of these complexes in a catalytic test reaction, namely the asymmetric aldol condensation of methyl 2-isocyanoacetate and benzaldehyde to form chiral dihydrooxazoles (Scheme 1).

Scheme 1. The Aldol Condensation of Methyl 2-Isocyanoacetate and Benzaldehyde

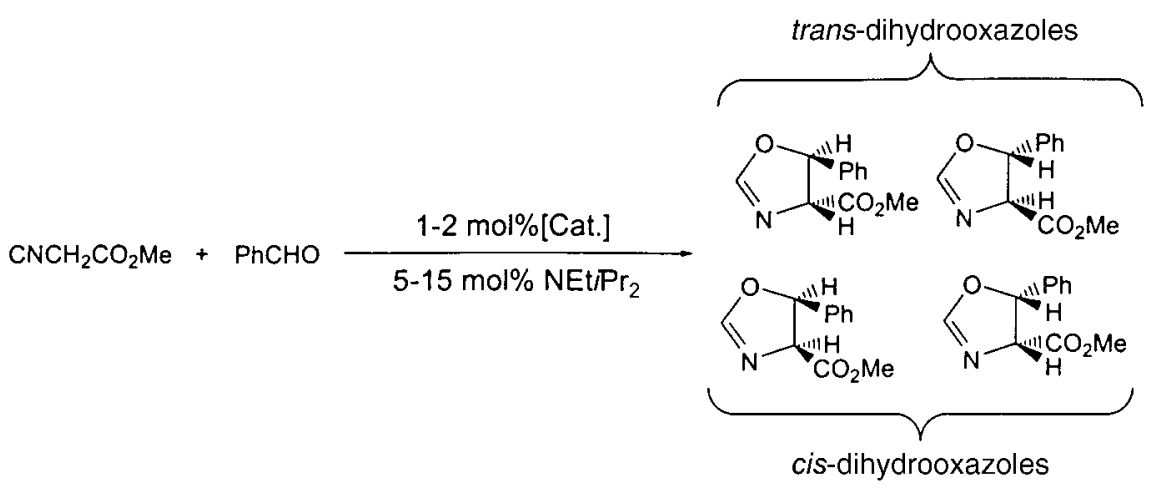

This asymmetric catalytic reaction was initially reported by Hayashi, Ito, and coworkers, who used a Au catalyst [15], and was also the subject of detailed further study by Togni and Pastor under similar conditions [16]. Pregosin and co-workers showed this reaction to be catalysed by $\mathrm{Pd}^{\mathrm{II}}$ centres as well [17]. This reaction is interesting both because it is a potential route to $\beta$-hydroxy-amino acids, and because it involves the formation of a $\mathrm{C}-\mathrm{C}$ bond with simultaneous creation of two chiral centres, resulting in

4) While not true pincer ligands in the strict sense as defined above, the tridentate ligands developed by Richards et al. ([14c] and references therein) as well as those of Bergman, Tilley, and co-workers [14d] are closely related, and should be kept in mind in discussions of this area. 
four possible stereoisomers. It is thus a useful test reaction for exploring the chiral induction provided by new, chiral Lewis acid catalysts.

In 1994, Venanzi and co-workers prepared a Pt complex of a [PCP] ligand, in which the benzylic positions of the ligand had been modified to form stereogenic centres [14a]. This complex was found to be an active catalyst for the aforementioned aldol condensation. While the enantiomeric excesses and diastereoisomeric selectivities obtained were moderate for this [PCP]-Pt complex, it was clearly demonstrated that this sort of species was capable of chiral induction. More recently, Zhang and coworkers have prepared Pd and Pt complexes of a similar chiral [PCP] ligand, and tested their activities in the same aldol condensation $[14 b]^{5}$ ). While selectivities remained modest, the synthetic approach used to synthesize the chiral ligand was considerably more straightforward than that of Venanzi and co-workers, thus increasing the potential usefulness of the system. In related studies, Giménez and Swager have prepared chiral [SCS]$\mathrm{Pd}$ complexes in which the chirality is located on a tail attached to C(4) of the [SCS] aryl ring, although no significant chiral induction was observed with this catalyst [19].

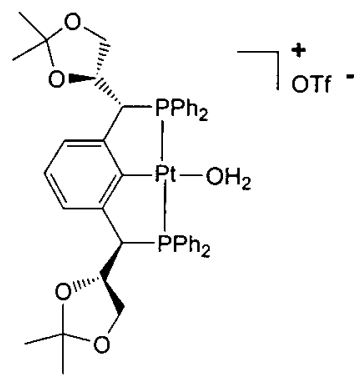

Venanzi and co-workers

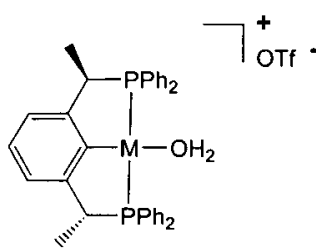

$\mathrm{M}=\mathrm{Pd}, \mathrm{Pt}$ Zhang and co-workers

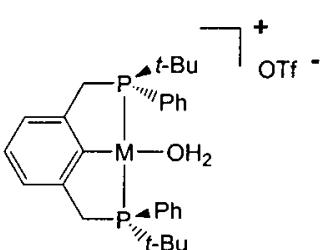

$M=P d, P t$

This work

Since previous attempts to catalyse this reaction with pincer-supported metal complexes had centered upon complexes containing the chiral information at the benzylic C-atom, it seemed a logical approach to synthesize catalysts with the chiral information to be found at the P-atom itself, since the binding pocket of square-planar [PCP] complexes is quite deep, and thus the R-groups bound to the $\mathrm{P}$-atom are in close proximity to a potential substrate. We therefore set out to prepare the $C_{2}$-symmetric complexes with sterically demanding R-groups.

Results and Discussion. - Preparation of P-Stereogenic PCP Ligands [ $\left.P^{*} C P^{*}\right]$. The racemic monophosphorus compound tert-butyl(phenyl)phosphane-borane $\mathbf{1}$ was prepared in reasonable $(67 \%)$ yield by a modification of the procedure of Imamoto et al. (Scheme 2) [20]. This secondary phosphine-borane can be deprotonated, as was shown by Wolfe and Livinghouse, by $\mathrm{BuLi}$ in $\mathrm{Et}_{2} \mathrm{O}$, in the presence of $(-)$-sparteine [21]. Warming this mixture to $30^{\circ}$ for $1 \mathrm{~h}$, followed by cooling and reaction with either 1,3-bis(bromomethyl)benzene or 1,3-bis(bromomethyl)-2-bromobenzene resulted in the formation of the terdentate $\left[\mathrm{P}^{*} \mathrm{CP} *\right]$ ligands $\mathbf{2 a}$ and $\mathbf{2 b}$, respectively, in diastereoisomerically pure form (yields $53 \%$ purified and $99 \%$ crude, resp.).

5) This same ligand has also been used for catalytic dehydrogenation with a Ru catalyst (see [18]). 


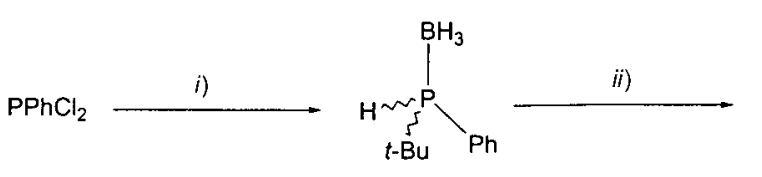

1

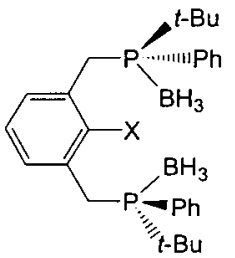

$X=H(2 a), B r(2 b)$

i) 1) $t$ - $\mathrm{BuLi}, \mathrm{Et}_{2} \mathrm{O},-78^{\circ}$; 2) $\mathrm{LiAlH}_{4}$, Filtration; 3) $\mathrm{Me}_{2} \mathrm{SBH}_{3}$. ii) 1) $\mathrm{BuLi},(-)$-sparteine, $\mathrm{Et}_{2} \mathrm{O},-78^{\circ}$; 2) $30^{\circ}$, $90 \mathrm{~min} ; 3)$ di- or tribromoxylene, $-78^{\circ}$.

The most striking spectral feature of these species is the sharp doublet $\left({ }^{3} J(\mathrm{P}, \mathrm{H})=\right.$ $14 \mathrm{~Hz}$ in both cases) assigned to the $t$-Bu group. If the alkylation of the bromoxylenes is carried out in the absence of $(-)$-sparteine or in THF in place of $\mathrm{Et}_{2} \mathrm{O}$, a mixture of both diastereoisomers is obtained, in which the $t$-Bu doublets of both diastereoisomers are clearly separated in the ${ }^{1} \mathrm{H}-\mathrm{NMR}$ spectrum. Presumably in the latter case, the THF coordinates strongly to the $\mathrm{Li}^{+}$cation, preventing sparteine complexation, thereby rendering the reaction completely nonstereoselective. The Me analogue of $\mathbf{2 a}, 1,3-$ $\left(\mathrm{PMePh}\left(\mathrm{BH}_{3}\right) \mathrm{CH}_{2}\right)_{2} \mathrm{C}_{6} \mathrm{H}_{4}$, can be prepared from $\mathrm{PHMePh}\left(\mathrm{BH}_{3}\right)$ and 1,3-bis(bromomethyl)benzene, yet surprisingly, even when the reaction has been performed in $\mathrm{Et}_{2} \mathrm{O}$ and in the presence of (-)-sparteine, an equimolar mixture of diastereoisomers has been obtained. This is presumably a result of the difference in steric congestion between the lithium methyl-phosphide-sparteine complex and the lithium tert-butylphosphide-sparteine complex.

Epimerization of Free Phosphine Centres. The phosphine-boranes 2a,b can be deprotected with an excess of various types of amines [20][21] $\left.{ }^{6}\right)$ to form the related phosphines 3a,b, which are potential [ $\left.\mathrm{P}^{*} \mathrm{CP} *\right]$ ligand precursors (Scheme 3$)$. Since the usefulness of these ligands is dependant upon their barrier to epimerization, a sample of 3a was deprotected with $\mathrm{Et}_{2} \mathrm{NH}$, the volatiles were removed, and $\mathrm{C}_{6} \mathrm{D}_{6}$ was added via vacuum transfer. The epimerization of $\mathbf{3 a}$ at $80^{\circ}$ was monitored by ${ }^{1} \mathrm{H}-\mathrm{NMR}$ in a $J$. Young NMR tube. A barrier of $28.1 \pm 0.1 \mathrm{kcal} / \mathrm{mol}$ was determined for the loss of chiral purity $\left.{ }^{7}\right)$. Such an inversion barrier is actually rather low for phenyldialkyl phosphines [22], but sufficiently high that epimerization of metal catalysts derived from this ligand would not be a significant consideration, as quaternerization of the P-atom makes it configurationally stable ${ }^{8}$ ).

${ }^{6}$ ) The most convenient methods have been the use of pyrrolidine (neat, $40^{\circ}, c a .12 \mathrm{~h}$ ) or $\mathrm{Et}_{2} \mathrm{NH}(50 / 50$ mixture with THF, $55^{\circ}, 1.5 \mathrm{~h}$ ). The amine can be subsequently removed by evaporation. No sign of inversion has been observed under these relatively mild conditions, though epimerization becomes rapid at higher temperatures and over longer times (vide infra). In contrast to the report in [21], we have not been able to remove the amine-boranes by sublimation.

7) This barrier is for the rac to meso epimerization, and was determined by use of the Eyring equation. $K_{\text {eq }}(375 \mathrm{~K})=0.33$, thus the $r a c$ form is slightly more stable, so the barrier for meso-to-rac epimerization is $27.3 \mathrm{kcal} / \mathrm{mol}$.

8) Assuming a very minimal metal-P bond energy of $17 \mathrm{kcal} / \mathrm{mol}\left(k_{\mathrm{dissoc}}>1 \mathrm{~s}^{-1}\right.$ at $\left.25^{\circ}\right)$, this would provide a barrier $>40 \mathrm{kcal} / \mathrm{mol}$ to inversion $\left(k_{\text {epim }}<5 \cdot 10^{-10} \mathrm{~s}^{-1}\right.$ at $120^{\circ}, t_{1 / 2}>40$ years; assuming entropy effects upon the epimerization rate are relatively minor). 
Scheme 3. Transition Metal Complexes of [ $\left.P^{*} C P^{*}\right]$ Ligands
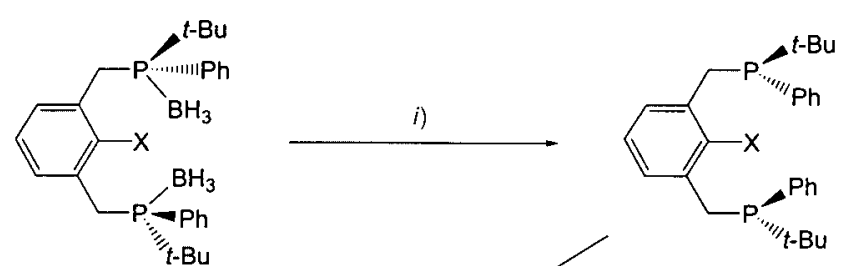

$X=H(2 a), B r(2 b)$

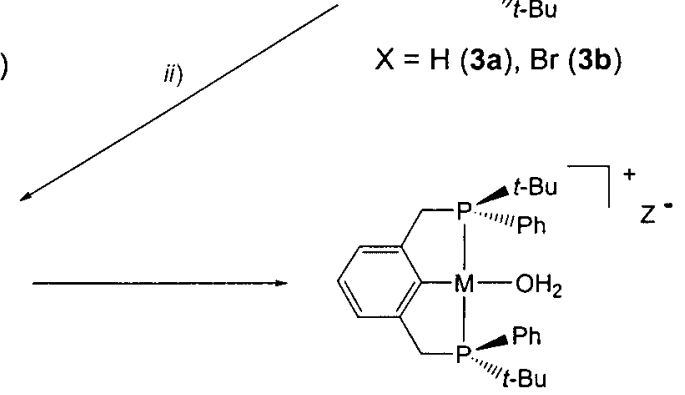

$M=P d, Y=C l(4 a), Y=B r(4 b)$

$\mathrm{M}=\mathrm{Pt}, \mathrm{Y}=\mathrm{Br}(\mathbf{5})$

$$
\begin{aligned}
& M=P d, Z=B F_{4}(6 a), Z=\operatorname{OTf}(6 b) \\
& M=P t, Z=B r(7)
\end{aligned}
$$

i) $\mathrm{HNR}_{2}$. ii $)$ For 4a: 3a $+\left[\mathrm{Pd}(\mathrm{MeCN})_{4}\right]\left[\mathrm{BF}_{4}\right]_{2}$ in $\mathrm{MeCN}, 60^{\circ}$ followed by $\mathrm{LiCl}$; for $\mathbf{4 b}: \mathbf{3 b}+\mathrm{Pd}_{2}(\mathrm{dba})_{3}$ in $\mathrm{C}_{6} \mathrm{H}_{6}$, $22^{\circ}, 12 \mathrm{~h}$; for $\mathbf{5}: \mathbf{3 b}+\mathrm{Pt}_{2}(p \text {-tolyl })_{4}\left(\mu-\mathrm{SEt}_{2}\right)_{2}, \mathrm{C}_{6} \mathrm{H}_{6}, 55^{\circ}, 5 \mathrm{~min}[23]$.

Transition Metal Complexes of $\left[P^{*} C P^{*}\right]$ Ligands. Complexes of the form $\left[\mathrm{P}^{*} \mathrm{CP} *\right] \mathrm{MY}(\mathrm{M}=\mathrm{Pd}, \mathrm{Y}=\mathrm{Cl},(\mathbf{4 a}) ; \mathrm{M}=\mathrm{Pd}, \mathrm{Y}=\mathrm{Br},(\mathbf{4 b}) ; \mathrm{M}=\mathrm{Pt}, \mathrm{Y}=\mathrm{Br},(\mathbf{5}))$ can be formed by metallation of the deprotected ligands $\mathbf{3 a}$ (for $\mathbf{4 a}$ ) or $\mathbf{3 b}$ (for $\mathbf{4 b}$ and $\mathbf{5}$ ), from the appropriate organometallic precursors (Scheme 3). All of the complexes have been characterized by multinuclear $\left({ }^{1} \mathrm{H},{ }^{13} \mathrm{C},{ }^{31} \mathrm{P}\right)$ NMR and polarimetry, while $4 \mathbf{a}$ and 5 were additionally characterized by X-ray crystallography.

Crystals of 4a suitable for X-ray crystallography were obtained by crystallization from $\mathrm{CH}_{2} \mathrm{Cl}_{2} /$ hexane, while those of $\mathbf{5}$ were obtained from toluene/pentane. Molecular plots of $\mathbf{4 a}$ and $\mathbf{5}$ are shown in Figs. 1 and 2, and selected bond lengths, angles, and dihedral angles are given in the Table. Compound $\mathbf{4 a}$ has approximate $C_{2}$ symmetry, while compound 5 crystallizes with two molecules in the asymmetric unit, which both have an exact, crystallographic $C_{2}$ symmetry. The dihedral angle of the aryl plane and the coordination plane is $14.46(10)^{\circ}$ in $\mathbf{4 a}$, and $9.81(6)^{\circ}$ and $10.01(6)^{\circ}$ in $\mathbf{5}$. The most interesting feature of these crystal structures is the fact that the $t$-Bu groups of the phosphine are oriented out and away from the ligand in the direction of the halide, whereas the $\mathrm{Ph}$ groups of the phosphine are held nearly perpendicular to the square plane of the complex $\left(88.18(11)^{\circ}\right.$ and $93.01(11)^{\circ}$ for the two $\mathrm{Cl}-\mathrm{P}-\mathrm{Pd}-\mathrm{C}$ (ipso)torsion angles in $\mathbf{4 a}$ ). This effect is less pronounced in the Pt structure, in which the same torsion angles of the $\mathrm{Ph}$ groups are reduced to $78.07(7)^{\circ}$ and $84.89(6)^{\circ}$.

When the complexes (especially that of Pd, 4a) are viewed along the halogen-metal axis, two of the four quadrants are occupied by $t$-Bu groups, while two are relatively empty due to the distance of the $\mathrm{Ph}$ groups. This creates a deep chiral pocket around the halogen, which could potentially have a strong chiral induction in reactions in which a substrate is bound in the position occupied by the halogen. Cross et al. have named this 


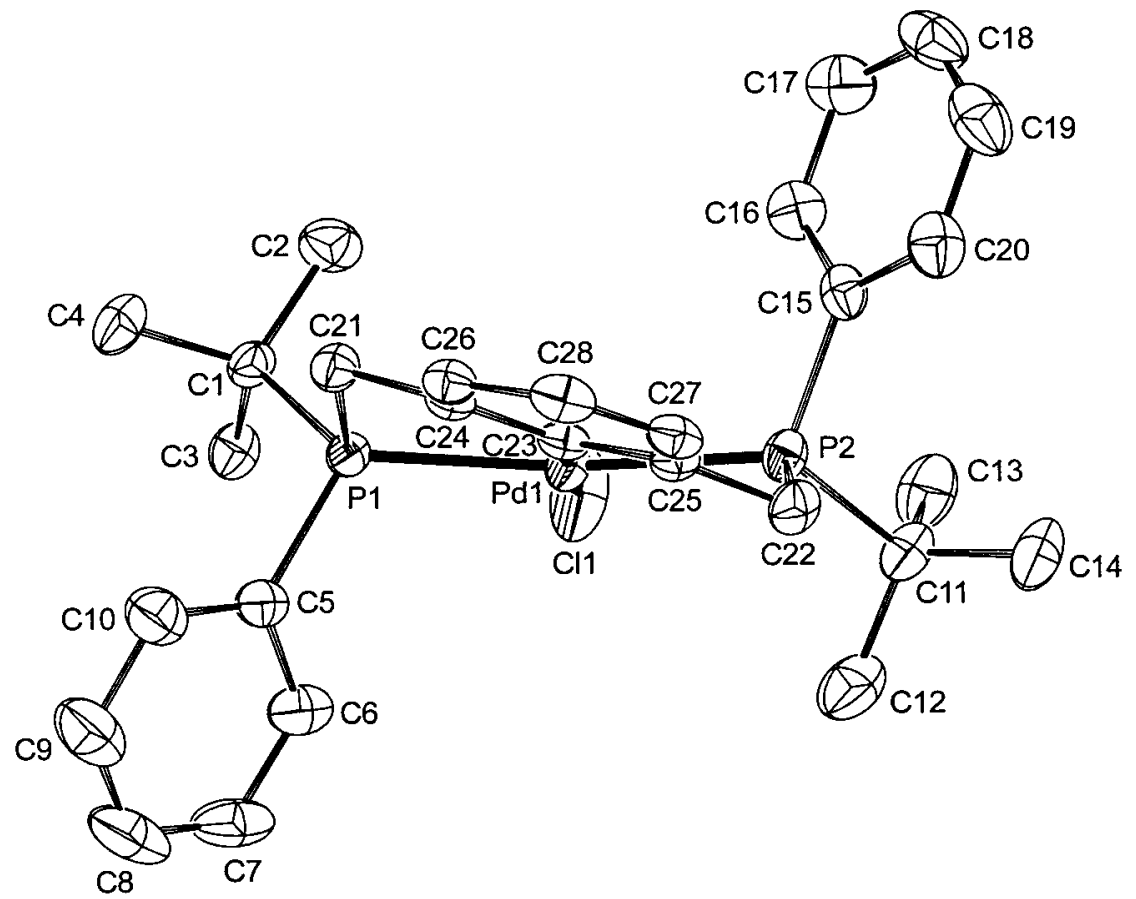

Fig. 1. Displacement ellipsoid plot of $\mathbf{4 a}$ (50\% probability). H-Atoms omitted for clarity.

a 'staggered' configuration in their analysis of pincer and pincer-type ligand structures [24]. The contrasting situation, or 'eclipsed' form, would place all four phosphine substituents evenly distanced from the square plane of the metal, thus placing large bulky groups in all four quadrants, which would be expected to give much less selectivity, and to dramatically slow the rate of catalysis.

Reaction of complexes $\mathbf{4}$ and $\mathbf{5}$ with $\mathrm{AgZ}$ in wet acetone affords the corresponding cationic aqua complexes $\mathbf{6}$ and $\mathbf{7}\left(\mathrm{M}=\mathrm{Pd}, \mathrm{Z}=\mathrm{BF}_{4}, \mathbf{6 a} ; \mathrm{M}=\mathrm{Pd}, \mathrm{Z}=\mathrm{OTf}, \mathbf{6 b} ; \mathrm{M}=\mathrm{Pt}\right.$, $\mathrm{Z}=$ OTf, 7). Complex $\mathbf{6 b}$ has been synthesized on a preparative scale $(452 \mathrm{mg}, 95 \%)$ and fully characterized by elemental analysis, multinuclear NMR $\left({ }^{1} \mathrm{H},{ }^{31} \mathrm{P}\right)$, and polarimetry. Since we were interested in the application of these catalysts to the aldol condensation of $\mathrm{CNCH}_{2} \mathrm{CO}_{2} \mathrm{Me}$ with aldehydes, $\mathrm{CNCH}_{2} \mathrm{CO}_{2} \mathrm{Me}$ was added to $\mathbf{6 b}$ to form the isocyanate adduct 8 , which was spectroscopically $\left({ }^{1} \mathrm{H}-,{ }^{13} \mathrm{C}-\mathrm{NMR}\right.$; IR $)$ characterized. The change in $v_{\mathrm{CN}}\left(\Delta v=56 \mathrm{~cm}^{-1}\right)$ between free $\mathrm{CNCH}_{2} \mathrm{CO}_{2} \mathrm{Me}$ and 8 indicates that the isocyanate is bound through the isocyanate $\mathrm{C}$-atom.

Chiral Aldol Condensation Reaction. The complexes 6a,b are active catalysts in the aldol condensation of methyl 2-isocyanoacetate with benzaldehyde. The product of this reaction, methyl 4,5-dihydro-5-phenyl-1,3-oxazoline-4-carboxylate exists in four isomeric forms: two $(E)$-enantiomers and two $(Z)$-enantiomers. Previous work by the groups of Venanzi and Zhang has demonstrated that the reaction has some enantioselectivity when performed with catalysts in which the chiral information is located at the benzyl C-atom of the [PCP]-Pt and -Pd catalysts (see Introduction) 


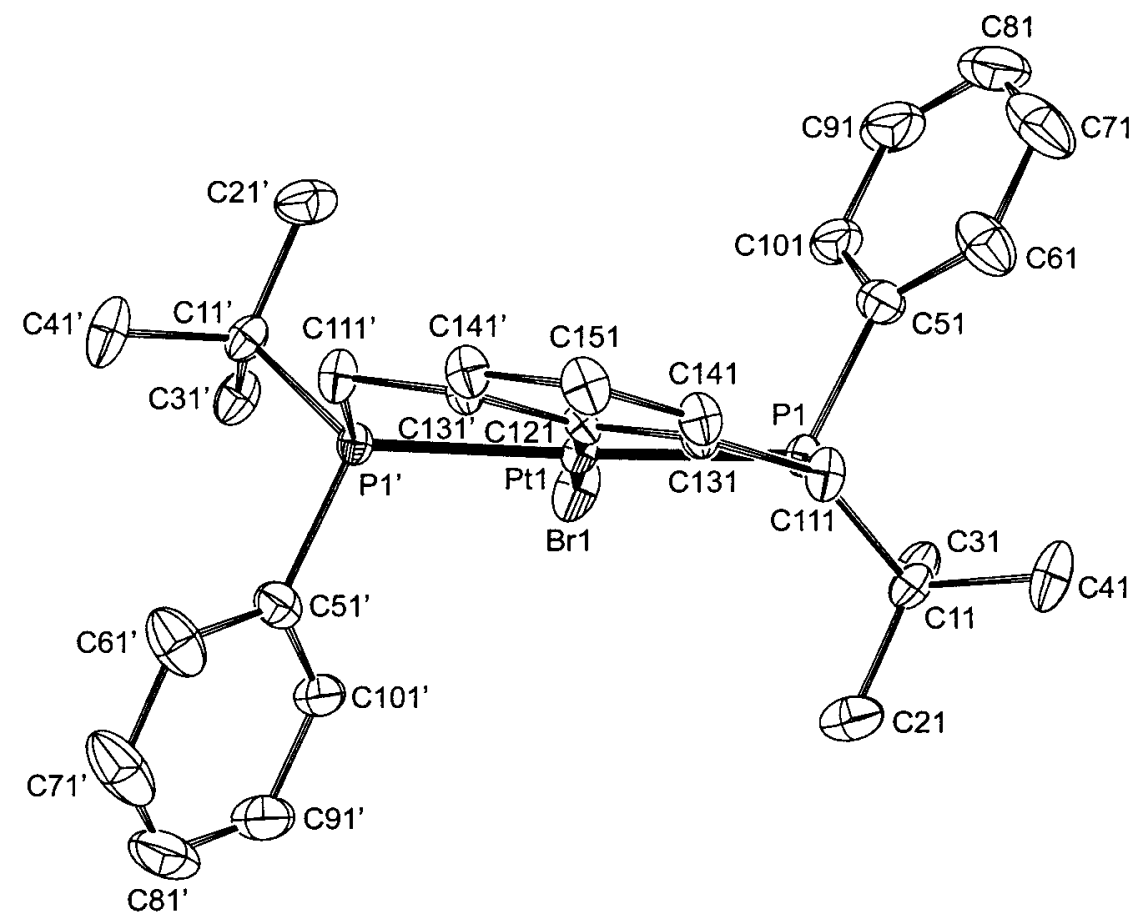

Fig. 2. Displacement ellipsoid plot of the first independent molecule of $\mathbf{5}$ (50\% probability). H-Atoms omitted for clarity. Symmetry operation: $1-x, y,-z$.

Table. Selected Bond Lengths, Angles, and Torsion Angles for $\mathbf{4 a}$ and $\mathbf{5}$

\begin{tabular}{|c|c|c|c|c|}
\hline & $4 a$ & & 5 & \\
\hline \multirow[t]{6}{*}{ Bond lengths $[\AA]$} & $\mathrm{Pd}-\mathrm{Cl}$ & $2.3571(12)$ & $\mathrm{Pt}-\mathrm{Br}$ & $2.5430(4)$ \\
\hline & $\mathrm{Pd}-\mathrm{C}(23)$ & $2.011(3)$ & $\mathrm{Pt}^{\prime}-\mathrm{Br}^{\prime}$ & $2.5442(4)$ \\
\hline & $\mathrm{Pd}-\mathrm{P}(1)$ & $2.2975(8)$ & $\mathrm{Pt}-\mathrm{C}(121)$ & $2.021(3)$ \\
\hline & $\mathrm{Pd}-\mathrm{P}(2)$ & $2.2947(8)$ & $\mathrm{Pt}^{\prime}-\mathrm{C}(122)$ & $2.016(3)$ \\
\hline & & & $\mathrm{Pt}-\mathrm{P}$ & $2.2926(5)$ \\
\hline & & & $\mathrm{Pt}^{\prime}-\mathrm{P}^{\prime}$ & $2.2928(6)$ \\
\hline \multirow[t]{4}{*}{ Bond Angles $\left[{ }^{\circ}\right]$} & $\mathrm{Cl}-\mathrm{Pd}-\mathrm{P}(1)$ & $99.55(3)$ & $\mathrm{Br}-\mathrm{Pt}-\mathrm{P}$ & $96.73(1)$ \\
\hline & $\mathrm{Cl}-\mathrm{Pd}-\mathrm{P}(2)$ & $96.34(3)$ & $\mathrm{Br}^{\prime}-\mathrm{Pt}^{\prime}-\mathrm{P}^{\prime}$ & $97.16(1)$ \\
\hline & $\mathrm{C}(23)-\mathrm{Pt}-\mathrm{P}(1)$ & $82.22(8)$ & $\mathrm{C}(121)-\mathrm{Pt}-\mathrm{P}$ & $83.27(1)$ \\
\hline & $\mathrm{C}(23)-\mathrm{Pt}-\mathrm{P}(2)$ & $81.86(8)$ & $\mathrm{C}(122)-\mathrm{Pt}^{\prime}-\mathrm{P}^{\prime}$ & $82.84(1)$ \\
\hline \multirow[t]{4}{*}{ Dihedral Angles $\left[{ }^{\circ}\right]$} & $\mathrm{Cl}-\mathrm{Pd}-\mathrm{P}(1)-\mathrm{C}(1)$ & $-40.21(10)$ & $\mathrm{Br}-\mathrm{Pt}-\mathrm{P}-\mathrm{C}(11)$ & $-48.94(9)$ \\
\hline & $\mathrm{Cl}-\mathrm{Pd}-\mathrm{P}(2)-\mathrm{C}(11)$ & $-36.00(14)$ & $\mathrm{Br}^{\prime}-\mathrm{Pt}^{\prime}-\mathrm{P}^{\prime}-\mathrm{C}(12)$ & $-43.84(9)$ \\
\hline & $\mathrm{Cl}-\mathrm{Pd}-\mathrm{P}(1)-\mathrm{C}(5)$ & 88.19(13) & $\mathrm{Br}-\mathrm{Pt}-\mathrm{P}-\mathrm{C}(51)$ & 78.07(7) \\
\hline & $\mathrm{Cl}-\mathrm{Pd}-\mathrm{P}(2)-\mathrm{C}(15)$ & $93.01(13)$ & $\mathrm{Br}^{\prime}-\mathrm{Pt}^{\prime}-\mathrm{P}^{\prime}-\mathrm{C}(52)$ & $84.90(7)$ \\
\hline
\end{tabular}

[14a,b]. (E/Z)-Ratios of $70 / 30$ and $78 / 22$, and e.e. values of $65 \%$ and $24 \%$ were reported for the $(E)$-isomers, respectively. In both cases, the chirality of these complexes was located on the benzylic C-atom of the [PCP] ligand.

We anticipated that moving the chiral site closer to the substrate binding pocket by the synthesis of a P-chiral version of the [PCP] ligand would increase the enantio- and 
diastereoselectivity of the reaction. Indeed, for the Pd complexes 6 , the diastereoisomeric ratio was found to be higher, yielding 94-98\% (E)-product. However, the enantiomeric excess was never found to be higher than $11 \%$. Variations of the concentration of catalyst, aldehyde, and Hünig's base did not appreciably affect the enantioselectivity, nor did changing the reaction solvent from $\mathrm{CH}_{2} \mathrm{Cl}_{2}$ to THF or toluene. Use of the isocyanate adduct $\mathbf{8}$, under anhydrous conditions also showed no appreciable enantioselectivity. In contrast to the experience of Venanzi and co-workers [14a], we found the $\mathrm{Pt}$ analogue 7 of our catalyst to be slower than the blank reaction that occurs in the absence of transition metal catalyst. This is presumably due to the greater steric bulk about the open site of our catalyst relative to that of Venanzi and coworkers.

It is perhaps not surprising that our $\left[\mathrm{P}^{*} \mathrm{CP} *\right]$ catalyst displays a lower enantioselectivity than that of the Au catalyst of Hayashi and co-workers [15], as the selectivity of the latter has been ascribed to a H-bonding interaction with a pendant amino group, which is lacking in the $\mathrm{Pd} / \mathrm{Pt}$ system. However, it is striking that the enantioselectivity is not higher than that of the other [PCP]-Pd/Pt-pincer systems discussed above in which the chirality is more distant from the active site of the catalyst. Further investigation of other reactions of these $\left[\mathrm{P}^{*} \mathrm{CP} *\right]$ catalysts will be necessary before nonspeculative explanations can be advanced, and these are underway in our laboratory.

Conclusions. - The wide use and versatility of pincer ligands in catalysis, and especially advances in macromolecular pincer catalysts that can be recycled with high efficiency by current and developing techniques, makes the development of new pincerbased systems a very attractive field of catalyst development. To date, pincer-based systems have shown poor to moderate enantioselectivities in catalytic reactions that result in chiral products. We have shown that it is possible to prepare enantiomerically pure transition metal pincer complexes with chirality at the P-atoms themselves which are directly bonded to the transition metal. An initial test reaction between methyl 2isocyanoacetate and benzaldehyde did not generate high enantiomeric excesses, though this does not preclude the possibility of enantioselectivity in other reactions. We are currently involved in the use of these ligands with other metals and catalytic reactions, as well as the synthesis of related P-stereogenic pincer ligands in order to find systems in which our techniques for recoverable catalyst synthesis can be applied to useful asymmetric transformations.

This material is based upon work supported by the North Atlantic Treaty Organization (NATO) under a grant awarded in the year 2000 (to B. S. W.). Any opinions, findings, and conclusions or recommendations expressed in this publication are those of the authors and do not necessarily reflect the view of NATO. A. L. S. and M. L. acknowledge funding from the Council for the Chemical Sciences of the Dutch Organization for Scientific Research (CW-NWO) and P. D. acknowledges funding from the Conselho Nacional de Desenvolvimento Cientifico e Tecnológico of Brazil. B. S. W. would like to thank H. P. Dijkstra and Dr. S. Medici for helpful discussions.

\section{Experimental Part}

General. Unless otherwise noted, all transformations were carried out under $\mathrm{N}_{2}$, by standard Schlenk techniques, or under vacuum. Recrystallizations were performed under ambient atmosphere, either at r.t. or $-30^{\circ}$. Both protio- and deutero-solvents were purified by standard methods in reactions run under $\mathrm{N}_{2}$. $\mathrm{Et}_{2} \mathrm{NH}$ and pyrrolidine were degassed before use. 1,3-Bis(bromomethyl)-2-bromobenzene [25] and $\mathrm{Pt}_{2}(p \text {-tolyl })_{4}(\mu$ - 
$\left.\mathrm{SEt}_{2}\right)_{2}$ [23] were prepared according to published literature procedures. Other reagents, unless specified, were used as received from commercial suppliers or prepared by inorganic synthesis procedures. Enantiomeric excesses in catalytic reactions were determined by chiral HPLC, while diastereoisomeric ratios were determined by NMR.

Preparation of (tert-Butyl)(phenyl)phosphine-borane (1). This preparation is a variant upon that published by Imamoto and co-workers [20]. In a typical experiment, a flame-dried Schlenk flask was charged with a stir bar, $\mathrm{PPhCl}_{2}(5.80 \mathrm{~g}, 32.4 \mathrm{mmol})$, and dry ether $(100 \mathrm{ml})$. The reaction vessel was cooled to $-78^{\circ}$ and $t$-BuLi (1.5M soln. in pentane, $28 \mathrm{ml}, 42 \mathrm{mmol}$ ) was added dropwise via syringe over the course of $0.5 \mathrm{~h}$. The mixture was allowed to stir at $-78^{\circ}$ for $1.5 \mathrm{~h}$, after which the temp. was raised to r.t. over the course of another $1.5 \mathrm{~h}$. The temp. was subsequently reduced to $-41^{\circ}$, and $\mathrm{LiAlH}_{4}(1.43 \mathrm{~g}, 37.6 \mathrm{mmol})$ was added in a single portion. The cooling bath was removed, and the mixture filtered through Celite on sintered glass under $\mathrm{N}_{2}$. The solids were washed with dry ether $(2 \times 20 \mathrm{ml})$ and borane dimethyl sulphide complex $(16.2 \mathrm{ml}, 94 \%, 158 \mathrm{mmol})$ was added via syringe at $0^{\circ}$. This was allowed to stir for $0.5 \mathrm{~h}$ at r.t. before being carefully poured onto a mixture of ice $(100 \mathrm{~g})$ and $4 \mathrm{M} \mathrm{HCl}(50 \mathrm{ml})$. The org. layer was separated and the aq. layer washed twice with ether $(2 \times 50 \mathrm{ml})$. The combined org. layers were washed with $\mathrm{H}_{2} \mathrm{O}(50 \mathrm{ml})$ and brine $(50 \mathrm{ml})$ before being dried $\left(\mathrm{MgSO}_{4}\right)$ and filtered. The crude product was dissolved in $\mathrm{CH}_{2} \mathrm{Cl}_{2}(100 \mathrm{ml})$ and filtered through silica to give a heavy oil upon evaporation of the $\mathrm{CH}_{2} \mathrm{Cl}_{2}(3.90 \mathrm{~g}, 67 \%)$.

Synthesis of (S,S) 1,3-( $\left.\left(\mathrm{P}^{\mathrm{BH}} \mathrm{H}_{3}\right)\left({ }^{\mathrm{H}} \mathrm{Bu}\right)(\mathrm{Ph}) \mathrm{CH}_{2}\right)_{2}\left(\mathrm{C}_{6} \mathrm{H}_{4}\right)$ (2a) and $(\mathrm{S}, \mathrm{S}) \quad 1,3-\left(\mathrm{P}\left(\mathrm{BH}_{3}\right)(\mathrm{tBu})(\mathrm{Ph}) \mathrm{CH}_{2}\right)_{2}(2-$ $B r) C_{6} H_{3}(\mathbf{2 b})$. This preparation was derived from the method of sparteine resolution described by Wolfe and Livinghouse [21]. 2a and $\mathbf{2 b}$ were prepared by identical methods from $\mathbf{1}$ and either 1,3-bis(bromomethyl) benzene (2a) or 1,3-bis(bromomethyl)-2-bromobenzene (2b). The synthesis and characterization of $\mathbf{2 a}$ is given here. Phosphine - borane $\mathbf{1}(3.90 \mathrm{~g}, 21.7 \mathrm{mmol})$ was placed in a Schlenk flask with a stirbar, (-)-sparteine $(7 \mathrm{ml}$, $29 \mathrm{mmol})$ and ether $(80 \mathrm{ml})$. The temp. was lowered to $-78^{\circ}$, and BuLi $(1.6 \mathrm{M}$ soln. in pentane, $16.7 \mathrm{ml}$, $8.8 \mathrm{mmol}$ ) was added dropwise via syringe. We have noticed that it is essential to have more (-)-sparteine than BuLi present in order to ensure the formation of only one isomer. Within minutes, a voluminous white precipitate had formed. After $0.5 \mathrm{~h}$, the cooling bath was removed, and the reaction allowed to come to r.t. over the course of $0.5 \mathrm{~h}$. The reaction was placed in a warm water bath $\left(\mathrm{ca} .30^{\circ}\right)$ for $1.5 \mathrm{~h}$ in order to allow the sparteine-lithiumphosphide complex to form the desired isomer. Subsequently, the temp. was reduced to $-78^{\circ}$ and $1,3-$ bis(bromomethyl)benzene was added, and the reaction warmed to $-20^{\circ}$ over the course of $2 \mathrm{~h}$ before being placed in the freezer $\left(-30^{\circ}\right)$ overnight. The reaction was poured into toluene $(100 \mathrm{ml}), \mathrm{CH}_{2} \mathrm{Cl}_{2}(200 \mathrm{ml})$, and $3 \% \mathrm{H}_{2} \mathrm{SO}_{4}(200 \mathrm{ml})$, the org. layer separated, and the aq. layer extracted thrice with $\mathrm{CH}_{2} \mathrm{Cl}_{2}(100,100$, and $50 \mathrm{ml}$ ). The combined org. fractions were reduced to $150 \mathrm{ml}$, and washed (aq. $\left.\mathrm{Na}_{2} \mathrm{CO}_{3}, 50 \mathrm{ml}\right)$ and brine $(50 \mathrm{ml})$. The solvents were evaporated, the product passed through silica in $\mathrm{CH}_{2} \mathrm{Cl}_{2}$, and subsequently precipitated with hexane $(2.09 \mathrm{~g}, 42 \%, 2$ crops $) .[\alpha]_{\mathrm{D}}^{23}=+106\left(c=0.21, \mathrm{CHCl}_{3}\right) .{ }^{1} \mathrm{H}-\mathrm{NMR}\left(\mathrm{CDCl}_{3}\right): 1.11\left(d,{ }^{3} J(\mathrm{P}, \mathrm{H})=13.8,22 \mathrm{H}\right.$ (includes some intensity from broad $\mathrm{BH}_{3}$ signal), $\left.\mathrm{P}-t-\mathrm{Bu}\right) ; 3.2-3.5$ (8 line $\mathrm{ABX}$ pattern, $4 \mathrm{H}$, diastereoisotopic $\left.\mathrm{P}-\mathrm{CH}_{2}\right) ; 6.9-7.0(m, \mathrm{H}-\mathrm{C}(3), \mathrm{H}-\mathrm{C}(4)$, and $\mathrm{H}-\mathrm{C}(5)$ of central aryl ring $) ; 7.18(s, \mathrm{H}-\mathrm{C}(1)$ of central aryl ring); $7.3-7.5(m, 6 \mathrm{H}, m$ - and $p$-signals of $\mathrm{P}-\mathrm{Ph}) ; 7.75\left(t,{ }^{3} J(\mathrm{P}, \mathrm{H})(\mathrm{H}, \mathrm{H})=8.1,4 \mathrm{H}, o\right.$-signals of $\left.\mathrm{P}-\mathrm{Ph}\right)$. ${ }^{13} \mathrm{C}-\mathrm{NMR}\left(\mathrm{CDCl}_{3}\right): 25.8\left(\mathrm{CMe}_{3}\right) ; 27.0,30.0\left(2 d, J=30.0, \mathrm{P}-\mathrm{CMe}_{3}\right.$ and $\left.\mathrm{P}-\mathrm{CH}_{2}\right) ; 126.0\left(d,{ }^{1} J(\mathrm{P}, \mathrm{C})=47\right.$, $\mathrm{P}-C\left(\right.$ ipso )); 127.9 (arom.); $128.2\left(d,{ }^{3} J(\mathrm{P}, \mathrm{C})=9, \mathrm{P}-C(\right.$ meta $)$ ); 128.8 (arom.); 131.2 (arom.); 132.7 (arom.); $133.9\left(d,{ }^{2} J(\mathrm{P}, \mathrm{C})=7, \mathrm{P}-C(\right.$ ortho $\left.)\right) .{ }^{31} \mathrm{P}-\mathrm{NMR}\left(\mathrm{CDCl}_{3}\right): 34$ (br. q). Anal. calc. for $\mathrm{C}_{28} \mathrm{H}_{42} \mathrm{~B}_{2} \mathrm{P}_{2}(462.21)$ : $\mathrm{C} 72.76$, H 9.16, P 13.40; found: C 72.52, H 9.08, P 13.46.

Compound $\mathbf{2 b}$ was isolated only in crude form $(3.22 \mathrm{~g}, 99 \%)$ and thus characterized spectroscopically: $[\alpha]_{\mathrm{D}}^{23}=+136\left(c=1.01, \mathrm{CH}_{2} \mathrm{Cl}_{2}\right) \cdot{ }^{1} \mathrm{H}-\mathrm{NMR}\left(\mathrm{CDCl}_{3}\right): 1.11\left(d,{ }^{3} \mathrm{~J}(\mathrm{P}, \mathrm{H})=13.8,22 \mathrm{H}\right.$ (includes some intensity from broad $\mathrm{BH}_{3}$ signal $), \mathrm{P}-t$-Bu $) ; 3.2-3.5\left(8\right.$ line $\mathrm{ABX}$ pattern, $4 \mathrm{H}$, diastereoisotopic $\left.\mathrm{P}-\mathrm{CH}_{2}\right) ; 6.9-7.0(m, 3 \mathrm{H}$, $\mathrm{H}-\mathrm{C}(3), \mathrm{H}-\mathrm{C}(4)$, and $\mathrm{H}-\mathrm{C}(5)$ of central aryl ring); $7.3-7.5(m, 6 \mathrm{H}, m$ - and $p$-signals of $\mathrm{P}-\mathrm{Ph}) ; 7.75$ $\left(t,{ }^{3} \mathrm{~J}(\mathrm{P}, \mathrm{H})(\mathrm{H}, \mathrm{H})=8.1,4 \mathrm{H}, o\right.$-signals of $\left.\mathrm{P}-\mathrm{Ph}\right) .{ }^{13} \mathrm{C}-\mathrm{NMR}\left(\mathrm{CDCl}_{3}\right): 25.9\left(\mathrm{CMe}_{3}\right) ; 27.5,30.5(2 d, J=30.0$, $\mathrm{P}-\mathrm{CMe}_{3}$ and $\left.\mathrm{P}-\mathrm{CH}_{2}\right) ; 126.0\left(d,{ }^{1} J(\mathrm{P}, \mathrm{C})=47, \mathrm{P}-C(\right.$ ipso $\left.)\right) ; 126.6($ arom. $) ; 128.6\left(d,{ }^{3} J(\mathrm{P}, \mathrm{C})=9, \mathrm{P}-C(\right.$ meta $)$; $129.1(t, J=6.1, C-\mathrm{Br}) ; 129.7$ (arom.); $131.6\left(d,{ }^{4} J(\mathrm{P}, \mathrm{C})=\sim 2, \mathrm{P}-C(\right.$ para $) ; 134.2\left(d,{ }^{2} J(\mathrm{P}, \mathrm{C})=7, \mathrm{P}-C(\right.$ ortho $\left.)\right)$; 134.6 (arom). ${ }^{31} \mathrm{P}-\mathrm{NMR}\left(\mathrm{CDCl}_{3}\right): 34$ (br. $q$ ).

Deprotection of Phosphine-Boranes to form 1,3-\{Bis[(tert-butyl)(phenyl)phosphino]methyl\}benzene and 1,3-\{Bis/tert-butyl(phenyl)phosphino]methyl\}-2-bromobenzene (3a,b): The phosphine-boranes 2a,b were deprotected by heating in neat pyrrolidine $\left(40^{\circ}, 12 \mathrm{~h}\right)$ or $50 / 50(\mathrm{v} / \mathrm{v})$ mixture of THF and $\mathrm{Et}_{2} \mathrm{NH}\left(55^{\circ}, 1.5 \mathrm{~h}\right)$ to afford the free phosphines 3a,b, respectively ( ${ }^{31} \mathrm{P}-\mathrm{NMR}$ : 8.5 (for 3a), 8.1 (for $\mathbf{3 b}$ )). The volatiles were removed under vacuum and the free phosphines directly used in metallation reactions without further purification.

Preparation of $\{(\mathrm{S}, \mathrm{S})-1,3-\{$ Bis [ (tert-butyl) (phenyl)phosphino]methyl $\}$ phenyl $\}$ chloropalladium (4a): Freshly deprotected 3a (from $585 \mathrm{mg}, 1.35 \mathrm{mmol}$ of 2a) was dissolved in $\mathrm{MeCN}$, and was allowed to react with 
$\left[\mathrm{Pd}(\mathrm{MeCN})_{4}\right]\left[\mathrm{BF}_{4}\right]_{2}(680 \mathrm{mg}, 1.5 \mathrm{mmol})$ over the course of $12 \mathrm{~h}$, after which a large quantity of palladium black had formed. $\mathrm{LiCl}(200 \mathrm{mg}, 7.5 \mathrm{mmol})$ in wet acetone was added to the soln., and after $1 \mathrm{~h}$, the solvents were removed in vacuo and the product extracted from the solids with $\mathrm{CH}_{2} \mathrm{Cl}_{2}$. A brown impurity was removed by $\mathrm{THF} / \mathrm{ether}$ precipitation, and the product was isolated by precipitation from ether/EtOH in two crops (118 mg, $15 \%$ (unoptimized)). $[\alpha]_{\mathrm{D}}^{23}=-129\left(c=0.21, \mathrm{CHCl}_{3}\right) .{ }^{1} \mathrm{H}-\mathrm{NMR}\left(\mathrm{CDCl}_{3}\right): 1.30\left(t,{ }^{3} J(\mathrm{P}, \mathrm{H})=7.7,2 t-\mathrm{Bu}\right) ; 3.62$ (br. $\left.m, 2 \mathrm{P}-\mathrm{CH}_{2}\right) ; 6.88(t, 7.2, \mathrm{H}-\mathrm{C}(4)$ of central aryl ring $) ; 7.05(d, J=7.5, \mathrm{H}-\mathrm{C}(3), \mathrm{H}-\mathrm{C}(5)$ of central aryl ring); 7.42 (br. $m, 6 \mathrm{H}, m$ - and $p$-signals of $\mathrm{P}-\mathrm{Ph}$ ); 8.07 (br. $m, 4 \mathrm{H}, o$-signal of $\mathrm{P}-\mathrm{Ph}$ ). ${ }^{13} \mathrm{C}-\mathrm{NMR}\left(\mathrm{CDCl}_{3}\right): 26.9$ $(\mathrm{CMe})$; 33.3, $35.6\left(2 t, J=11,5, \mathrm{P}-\mathrm{CMe}_{3}, \mathrm{P}-\mathrm{CH}_{2}\right) ; 123.3$ ( $t, J=11$, arom.); 125.6 (arom.); 128.5 (arom.); 129.9 $\left(t, J=16\right.$, arom.); 130.7 (arom.); 134.3 ( $t, J=3$, arom.); 148.1 ( $t, J=0$, arom.); 158.2 (arom.). ${ }^{31} \mathrm{P}-\mathrm{NMR}$ $\left(\mathrm{CDCl}_{3}\right)$ : 53.2. Anal. calc. for $\mathrm{C}_{28} \mathrm{H}_{35} \mathrm{ClP}_{2} \mathrm{Pd}$ (575.41): C 58.45, H 6.16; found: C 58.39, H 6.07.

Preparation of $\{(\mathrm{S}, \mathrm{S})-1,3-\{$ Bis [(tert-butyl)(phenyl)phosphino]methyl $\}$ phenyl\}bromopalladium (4b): Freshly deprotected 3a (from $3.06 \mathrm{~g}, 5.66 \mathrm{mmol}$ of $\mathbf{2 a}$ ) was dissolved in benzene, and was allowed to react with $\mathrm{Pd}_{2}(\mathrm{dba})_{3} \cdot \mathrm{CHCl}_{3}(2.75 \mathrm{~g}, 2.66 \mathrm{mmol})$ over the course of $12 \mathrm{~h}$. The product was filtered through silica in ether. Subsequently, the product was purified by column chromatography (silica, $\mathrm{CH}_{2} \mathrm{Cl}_{2}$ ) and crystallization from acetone/hexane at $-30^{\circ}\left(680 \mathrm{mg}, 19 \%\right.$ (unoptimized) as $\left.\mathbf{4 b} \cdot 1 / 3\left(\mathrm{C}_{2} \mathrm{H}_{6} \mathrm{O}\right)\right)$. The crystals were washed thrice with hexane. ${ }^{1} \mathrm{H}-\mathrm{NMR}\left(\mathrm{CDCl}_{3}\right): 1.35\left(t,{ }^{3} \mathrm{~J}(\mathrm{P}, \mathrm{H})=7.6,2, t\right.$-Bu $) ; 3.63$ (br. $\left.m, 2 \mathrm{P}-\mathrm{CH}_{2}\right) ; 6.85(t, J=7.4, \mathrm{H}-\mathrm{C}(4)$ of central aryl ring); $7.03(d, J=7.4, \mathrm{H}-\mathrm{C}(3), \mathrm{H}-\mathrm{C}(5)$ of central aryl ring); 7.41 (br. $m, 6 \mathrm{H}, m$ - and $p$-signals for $\mathrm{P}-\mathrm{Ph}) ; 8.05$ (br. $m, 4 \mathrm{H}, o$-signal for $\mathrm{P}-\mathrm{Ph}) .{ }^{13} \mathrm{C}-\mathrm{NMR}\left(\mathrm{CDCl}_{3}\right): 27.0\left(\mathrm{CMe}_{3}\right) ; 33.6,35.6\left(2 t, J=12, \mathrm{P}-\mathrm{CMe}_{3}\right.$ and $\left.\mathrm{P}-\mathrm{CH}_{2}\right) ; 123.3(t, J=10$, arom.); 125.6 (arom.); 128.5 (arom.); $129.7(t, J=20$, arom.); 130.6 (arom.); 134.3 (arom.); 147.6 (3t, $J=10$, arom.). ${ }^{31} \mathrm{P}-\mathrm{NMR}\left(\mathrm{CDCl}_{3}\right)$ : 54.0. Anal. calc. for $\mathrm{C}_{28} \mathrm{H}_{35} \mathrm{BrP}_{2} \mathrm{Pd}$ (619.76): C 54.43, H 5.49, P 10.03; found: C 54.26, H 5.38, P 10.03 .

Preparation of $\{(\mathrm{S}, \mathrm{S})-1,3-\{$ Bis [ (tert-butyl)(phenyl)phosphino]methyl $\}$ phenyl $\}$ bromoplatinum (5): Freshly deprotected $\left[\mathrm{P}^{*} \mathrm{C}(\mathrm{Br}) \mathrm{P}^{*}\right](\mathbf{3 b}$, from $930 \mathrm{mg}$ of $\mathbf{2 b}, 1.7 \mathrm{mmol})$ was suspended in benzene with $\mathrm{Pt}_{2}(p \text {-tolyl })_{4}(\mu-$ $\left.\mathrm{SEt}_{2}\right)_{2}(800 \mathrm{mg}, 0.86 \mathrm{mmol})$. The soln. was placed in a water bath at $55^{\circ}$. After $1 \mathrm{~min}$, the ${ }^{31} \mathrm{P}-\mathrm{NMR}$ spectrum of the crude mixture (unlocked, unreferenced) showed primarily signals for the product, $7,\left(\delta=50.0,{ }^{1} J(\mathrm{Pt}, \mathrm{P})=\right.$ $2895 \mathrm{~Hz})$, a small amount of starting material $(\delta=8.2)$, and a small amount of an intermediate, putatively assigned as the mono-phosphine-coordinated species cis- $\mathrm{Pt}(p \text {-tolyl })_{2}\left(\mathrm{SEt}_{2}\right)\left(\kappa^{1}-\mathbf{3 b}\right)\left(\delta=21.7,{ }^{1} \mathrm{~J}(\mathrm{Pt}, \mathrm{P}) \sim 1700 \mathrm{~Hz}\right.$; $\delta=8.8$ ). After $5 \mathrm{~min}$ at $55^{\circ}$, only the product was visible by ${ }^{31} \mathrm{P}-\mathrm{NMR}$ spectroscopy. The volatiles were removed

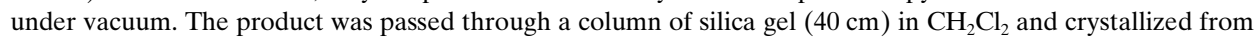
toluene/pentane $(0.599 \mathrm{~g}, 49 \%$ in two crops $) .[\alpha]_{\mathrm{D}}^{23}=-51 \quad\left(c=1.04, \mathrm{CH}_{2} \mathrm{Cl}_{2}\right) .{ }^{1} \mathrm{H}-\mathrm{NMR}\left(\mathrm{CDCl}_{3}\right): 1.42$ $\left(t,{ }^{3} \mathrm{~J}(\mathrm{P}, \mathrm{H})=7.7,2 t\right.$-Bu $) ; 3.65$ (br. $\left.m, 2 \mathrm{P}-\mathrm{CH}_{2}\right) ; 6.98(t, J=7.2, \mathrm{H}-\mathrm{C}(4)$ of central aryl ring); 7.09 ( $d$, with $\mathrm{Pt}$ satellites, ${ }^{3} J(\mathrm{H}, \mathrm{H})=7.5,{ }^{4} \mathrm{~J}(\mathrm{H}, \mathrm{Pt})=21, \mathrm{H}-\mathrm{C}(3), \mathrm{H}-\mathrm{C}(5)$ of central aryl ring); 7.43 (br. $m, 6 \mathrm{H}, m$ - and $p$-signals for $\mathrm{P}-\mathrm{Ph}) ; 8.14$ (br. $m, 4 \mathrm{H}, o$-signal or $\mathrm{P}-\mathrm{Ph}) .{ }^{13} \mathrm{C}-\mathrm{NMR}\left(\mathrm{CDCl}_{3}\right): 27.3\left(\mathrm{CMe}_{3}\right)$; 33.6, 36.2 (2t, with $\mathrm{Pt}$ satellites, $J(\mathrm{P}, \mathrm{C})=15,{ }^{2} J(\mathrm{Pt}, \mathrm{C})=59(33.6) ; J(\mathrm{P}, \mathrm{C})=16,{ }^{2} J(\mathrm{Pt}, \mathrm{C})=105(36.2) ; \mathrm{P}-\mathrm{CMe}_{3}$ and $\left.\mathrm{P}-\mathrm{CH}_{2}\right) ; 123.6(t$ with $\mathrm{Pt}$ satellites, $J(\mathrm{P}, \mathrm{C})=8, J(\mathrm{Pt}, \mathrm{C})=39$, arom. $) ; 124.9$ (arom.); $128.5(t, J=5$, arom. $) ; 130.8$ (arom.); $134.4(t, J=11$, arom.); 146.4 (arom.); 148.1 (arom.). ${ }^{31} \mathrm{P}-\mathrm{NMR}\left(\mathrm{CDCl}_{3}\right)$ : 49.9 (s, with Pt satellites, $\left.{ }^{1} J(\mathrm{Pt}, \mathrm{P})=2900\right)$.

Crystal-Structure Determinations: X-Ray intensities were measured on a Nonius KappaCCD diffractometer with rotating anode $(\lambda=0.71073 \AA)$ at a temp. of $150(2) \mathrm{K}$. The structures were solved with automated Patterson methods (DIRDIF 97) [26] and refined with SHELXL97 [27] against $F^{2}$ of all reflections. Molecular illustration, structure checking, and calculations were performed with the PLATON [28] package.

Crystal-Structure Determination of $\mathbf{4 a}$ : X-Ray-quality crystals of $4 \mathbf{a}$ were grown from a mixture of $\mathrm{CH}_{2} \mathrm{Cl}_{2} /$ hexane at r.t. by slow evaporation. $\mathrm{C}_{28} \mathrm{H}_{35} \mathrm{ClP}_{2} \mathrm{Pd}, F \mathrm{~W}=575.35$, colorless needle, $0.45 \times 0.06 \times 0.06 \mathrm{~mm}^{3}$, hexagonal, $P 6_{3}$ (No. 173), $a=b=20.3046(2), c=11.6707(1) \AA, V=4166.93(7) \AA^{3}, Z=6, \rho=1.376 \mathrm{~g} / \mathrm{cm}^{3} .81498$ reflections were measured. 6380 reflections were unique $\left(R_{\text {int }}=0.066\right) .5431$ reflections were observed $[I>$ $2 \sigma(I)]$. The $\theta$ range was $1.16-27.47^{\circ}$ with indices $\mathrm{hkl}-26 / 26,-26 / 26,-15 / 15$. The absorption correction was based on multiple measured reflections (program PLATON [28] routine MULABS, $\mu=0.89 \mathrm{~mm}^{-1}, 0.91-0.96$ transmission). Non-H-atoms were refined freely with anisotropic displacement parameters. H-atoms were refined as rigid groups. 295 refined parameters, 1 restraint. $R$-values [obs. refl.]: $R 1=0.0292, w R 2=0.0566$. $R$ values [all refl.]: $R 1=0.0429, \mathrm{w} R 2=0.0605 . G o F=1.022$. Flack $\mathrm{x}$-parameter $-0.05(2)$ [29]. Residual electron density between -0.49 and $0.65 \mathrm{e} / \AA^{3}$.

Crystal-Structure Determination of $\mathbf{5}$ : Crystals of $\mathbf{5}$ suitable for X-ray-diffraction study were grown from toluene/pentane. $\mathrm{C}_{28} \mathrm{H}_{35} \mathrm{BrP}_{2} \mathrm{Pt}, F \mathrm{w}=708.50$, colorless block, $0.33 \times 0.15 \times 0.15 \mathrm{~mm}^{3}$, monoclinic, $C 2$ (No. 5), $a=15.5173(1), b=13.0548(1), c=15.3827(1) \AA, \beta=118.7775(3)^{\circ}, V=2731.29(3) \AA^{3}, Z=4, \rho=1.723 \mathrm{~g} / \mathrm{cm}^{3}$. 60576 reflections were measured. 16878 reflections were unique $\left(R_{\text {int }}=0.033\right) .15320$ reflections were observed $[I>2 \sigma(I)]$. The $\theta$ range was $1.51-40.23^{\circ}$ with indices $\mathrm{hkl}-28 / 27,-23 / 23,-27 / 27$. An analytical absorption correction was applied (program PLATON [28], routine ABST, $\mu=6.73 \mathrm{~mm}^{-1}, 0.34-0.65$ transmission). The 
structure contains two independent molecules in the asymmetric unit, which both are located on a twofold axis. Non-H-atoms were refined freely with anisotropic displacement parameters. The $\mathrm{H}$-atoms of $\mathrm{Me}$ at $\mathrm{C}(21)$ and $\mathrm{C}(22)$ were refined freely with isotropic displacement parameters; all other $\mathrm{H}$-atoms were refined as rigid groups. 321 refined parameters, 49 restraints. $R$-values [obs. refl.]: $R 1=0.0243$, w $R 2=0.0466$. $R$-values [all refl.]: $R 1=0.0302, \mathrm{w} R 2=0.0481$. $G o F=1.031$. Flack x-parameter $-0.004(3)$ [29]. Residual electron density was between -2.16 and $0.90 \mathrm{e} / \AA^{3}$.

Crystallographic data (excluding structure factors) for the structures in this paper have been deposited with the Cambridge Crystallographic Data Centre as supplementary publication no. CCDC 169317 (4a) and 169318 (5). Copies of the data can be obtained, free of charge, on application to CCDC, 12 Union Road, Cambridge CB21EZ UK, (fax: + 441223336033 or e-mail: deposit@ccdc.cam.ac.uk).

Preparation of Aqua Complexes Aqua\{(S,S)-1,3-\{bis[(tert-butyl)(phenyl)phosphino]methyl $\}$ phenyl $\}$ palladium Tetrafluoroborate (6a), Trifluoroacetate (6b) and Aqua\{(S,S)-1,3-\{bis[(tert-butyl)(phenyl)phosphino]methyllphenyl\}platinum Bromide (7): As all three aqua complexes were prepared by the same method, that for $\mathbf{6 b}$ is given as typical. On the benchtop, a sample of $[\mathrm{PCP}] \mathrm{PdBr}(\mathbf{4 b})(430 \mathrm{mg}, 0.67 \mathrm{mmol})$ was dissolved in wet acetone. AgOTf (176 mg, $0.68 \mathrm{mmol})$ was added, which resulted in an off-white precipitate. After $1 \mathrm{~h}$, the sample was filtered through Celite on glass wool and precipitated with hexane as a microcrystalline white powder to form the product with one acetone molecule of crystallization $(452 \mathrm{mg}, 95 \%)$. $[\alpha]_{\mathrm{D}}^{23}=-13.5(c=1.04$, $\left.\mathrm{CH}_{2} \mathrm{Cl}_{2}\right) .{ }^{1} \mathrm{H}-\mathrm{NMR}\left(\mathrm{C}_{6} \mathrm{D}_{6}\right): 1.2 \mathrm{ppm}$ (br., $2 t$-Bu $) ; 1.54(6 \mathrm{H}$, acetone $) ; 3.0\left(4 \mathrm{H}, \mathrm{P}-\mathrm{CH}_{2}\right) ; 3.4-4.8\left(\mathrm{Pd}-\mathrm{OH} \mathrm{H}_{2}\right) ; 7$ (aryl signals); $7.1-8.2\left(\mathrm{P}-\mathrm{Ph}\right.$ signals). Aryl region not integratable due to $\mathrm{C}_{6} \mathrm{D}_{5} \mathrm{H}$ and overlap. Anal. calc. for $\mathrm{C}_{29} \mathrm{H}_{37} \mathrm{~F}_{3} \mathrm{O}_{4} \mathrm{P}_{2} \mathrm{PdS} \cdot\left(\mathrm{C}_{3} \mathrm{H}_{6} \mathrm{O}\right)$ (765.11): C 50.23, H 5.66, P 8.10; found: C 49.99, H 5.55, P 8.20.

For 7: $[\alpha]_{\mathrm{D}}^{23}=-57\left(c=0.76, \mathrm{CH}_{2} \mathrm{Cl}_{2}\right)$.

Isolation of Pd Isocyanate Complex (8): On the benchtop, [[PCP]Pd( $\left.\left.\mathrm{OH}_{2}\right)\right][\mathrm{OTf}](108.3 \mathrm{mg}, 0.14 \mathrm{mmol})$ was dissolved in acetone, to which methyl 2-isocyanoacetate $(14 \mu \mathrm{l}, 0.15 \mathrm{mmol})$ was added. The solvent was evaporated, and the product precipitated from THF/hexane $(84.1 \mathrm{mg}, 75 \%)$. $[\alpha]_{\mathrm{D}}^{23}=-34\left(c=0.23, \mathrm{CH}_{2} \mathrm{Cl}_{2}\right)$. IR: $1758 \mathrm{~cm}^{-1}(\mathrm{C}=\mathrm{O}), 2219 \mathrm{~cm}^{-1}(\mathrm{C} \equiv \mathrm{N}) .{ }^{1} \mathrm{H}-\mathrm{NMR}\left(\mathrm{CDCl}_{3}\right): 1.27\left(t,{ }^{3} J(\mathrm{P}, \mathrm{H})=8.1,2 t-\mathrm{Bu}\right) ; 3.8(\mathrm{br} . m, 2 \mathrm{P}-\mathrm{CH})$; $3.87(s, \mathrm{OMe}) ; 5.21\left(s, \mathrm{CNCH}_{2}\right) ; 7.03(t, J=7, \mathrm{H}-\mathrm{C}(4)$ of central aryl ring $) ; 7.13(d, J=7.5, \mathrm{H}-\mathrm{C}(3), \mathrm{H}-\mathrm{C}(5)$ of central aryl ring); 7.52 (br. $m, 6 \mathrm{H}, \mathrm{H}-\mathrm{C}(3), \mathrm{H}-\mathrm{C}(4), \mathrm{H}-\mathrm{C}(5)$ of $\mathrm{P}-\mathrm{Ph}) ; 7.73$ (br. $m, 4 \mathrm{H}, \mathrm{H}-\mathrm{C}(2), \mathrm{H}-\mathrm{C}(6)$ of $\mathrm{P}-\mathrm{Ph}) .{ }^{13} \mathrm{C}-\mathrm{NMR}\left(\mathrm{CDCl}_{3}\right): 26.6\left(\mathrm{CMe}_{3}\right) ; 33.0,36.5\left(2 t, J=12, \mathrm{P}-\mathrm{CMe}_{2}, \mathrm{P}-\mathrm{CH}_{2}\right) ; 47.3\left(s, \mathrm{CNCH}_{2}\right) ; 53.8$ $(s, \mathrm{OMe}) ; 123.7$ ( $t, J=10$, arom. $) ; 127.3$ ( $t, J=10$, arom. $) ; 127.9(t, J=20$, arom. ); 129.5 (arom.); 131.9 (arom.); 133.9 (arom.); $148.4(t, J=10$, arom. $) ; 162.8(s, \mathrm{Pd}-C \mathrm{~N}) ; 164.4(s, C=\mathrm{O})$. ${ }^{31} \mathrm{P}-\mathrm{NMR}\left(\mathrm{CDCl}_{3}\right)=71.0 . \mathrm{We}$ have been unable to obtain a satisfactory elemental analysis of compound $\mathbf{8}$, presumably due to loss of isonitrile ligand under high vacuum conditions.

Typical Catalytic Experiment for Aldol Condensation: A 20-ml vial was charged sequentially with $\left[[\mathrm{PCP}] \mathrm{Pd}\left(\mathrm{OH}_{2}\right)\left[\mathrm{BF}_{4}\right](\mathbf{6 a})(0.016 \mathrm{mmol}, 1 \mathrm{~mol}-\%), 5 \mathrm{ml}\right.$ of $\mathrm{CH}_{2} \mathrm{Cl}_{2}$ (distilled from $\left.\mathrm{CaH}_{2}\right)$, isonitrile (145 $\mu$, $1.60 \mathrm{mmol}, 100 \mathrm{~mol}-\%)$, benzaldehyde $(162 \mu \mathrm{l}, 1.59 \mathrm{mmol}, 100 \mathrm{~mol}-\%$, Hünig's base $(28 \mu \mathrm{l}, 0.16 \mathrm{mmol}, 10 \mathrm{~mol}-$ $\%)$, and mesitylene $(223 \mu \mathrm{l}, 1.60 \mathrm{mmol}, 100 \mathrm{~mol}-\%)$. The reaction was monitored by occasionally removing a $100-\mu \mathrm{l}$ aliquot, evaporation of the volatiles under a slow stream of $\mathrm{N}_{2}$, and dissolution in $\mathrm{CDCl}_{3} \mathrm{for}_{\mathrm{NMR}}$ spectroscopy.

\section{REFERENCES}

[1] C. L. Moulton, B. L. Shaw, J. Chem. Soc., Dalton Trans. 1976, 1020.

[2] a) M. Rietveld, D. M. Grove, G. van Koten, New J. Chem. 1997, 21, 751; b) G. van Koten, Pure Appl. Chem. 1989, 61, 1681 .

[3] F. Gorla, L. M. Venanzi, A. Albinati, Organometallics 1994, 13, 43.

[4] M. Ohff, A. Ohff, M. E. van der Boom, D. Milstein, J. Am. Chem. Soc. 1997, 119, 11697.

[5] a) D. M. Grove, G. van Koten, A. H. M. Verschuuren, J. Mol. Catal. 1988, 45, 169; b) D. M. Grove, A. H. M. Verschuuren, G. van Koten, J. A. M. van Beek, J. Organomet. Chem. 1989, 372, C1; c) A. Kleij, R. A. Gossage, R. J. M. Klein Gebbink, N. Brinkmann, E. J. Reijerse, U. Kragl, M. Lutz, A. L. Spek, G. van Koten, J. Am. Chem. Soc. 2000, 122, 12112.

[6] M. Gupta, C. Hagen, R. J. Flescher, W. C. Kaska, C. M. Jensen, Chem. Commun. 1996, 2083; M. Gupta, W. C. Kaska, C. M. Jensen, Chem. Commun. 1997, 461; W. W. Xu, G. P. Rosini, M. Gupta, C. M. Jensen, W. C. Kaska, K. Krogh-Jespersen, A. S. Goldman, Chem. Commun. 1997, 2273; F. Liu, E. B. Pak, B. Singh, C. M. Jensen, A. S. Goldman, J. Am. Chem. Soc. 1999, 121, 4086.

[7] P. Dani, T. Karlen, R. A. Gossage, S. Gladiali, G. van Koten, Angew. Chem., Int. Ed. 2000, $39,743$. 
[8] B. Rybtchinski, D. Milstein, Angew. Chem., Int. Ed. 1999, 38, 870; M. Kanzelberger, B. Singh, M. Czerw, K. Krogh-Jespersen, A. S. Goldman, J. Am. Chem. Soc. 2000, 122, 11017.

[9] J. W. J. Knapen, A. W. van der Made, J. C. de Wilde, P. W. N. M. van Leeuwen, P. Wijkens, D. M. Grove, G. van Koten, Nature 1994, 372, 659; R. A. Gossage, L. A. van de Kuil, G. van Koten, Acc. Chem. Res. 1998, 31, 423.

[10] H. P. Dijkstra, P. Steenwinkel, D. M. Grove, M. Lutz, A. L. Spek, G. van Koten, Angew. Chem., Int. Ed. 1999, 38, 2186; H. P. Dijkstra, M. D. Meijer, J. Patel, R. Kreiter, G. P. M. van Klink, M. Lutz, A. L. Spek, A. J. Canty, G. van Koten, Organometallics 2001, 20, 3159.

[11] L. A. van de Kuil, D. M. Grove, J. W. Zwikker, L. W. Jenneskens, W. Drenth, G. van Koten, Chem. Mater. 1994, 6, 1675.

[12] M. D. Meijer, N. Ronde, D. Vogt, G. P. M. van Klink, G. van Koten, Organometallics 2001, $20,3993$.

[13] C. Patmamanoharan, P. Wijkens, D. M. Grove, A. P. Philipse, Langmuir 1996, 12, 4372; C. Bezemer, R. J. M. Klein Gebbink, G. van Koten, submitted for publication.

[14] a) F. Gorla, T. Togni, L. M. Venanzi, A. Albertini, F. Lianza, Organometallics 1994, 13, 1607; b) J. M. Longmire, X. Zhang, M. Shang, Organometallics 1998, 17, 4374; c) M. A. Stark, G. Jones, C. J. Richards, Organometallics 2000, 19, 1282; d) M. Gerisch, J. R. Krumper, R. G. Bergman, T. D. Tilley, J. Am. Chem. Soc. 2001, 123, 5818.

[15] Y. Ito, M. Sawamura, T. Hayashi, J. Am. Chem. Soc. 1986, 108, 6405.

[16] A. Togni, S. D. Pastor, J. Org. Chem. 1990, 55, 1649.

[17] R. Nesper, P. S. Pregosin, K. Püntener, M. Wörle, Helv. Chim. Acta 1993, 76, 2239; R. Nesper, P. S. Pregosin, K. Püntener, M. Wörle, A. Albinati, J. Organomet. Chem. 1996, 507, 85.

[18] P. Dani, M. Albrecht, G. P. M. van Klink, G. van Koten, Organometallics 2000, 19, 4468.

[19] R. Giménez, T. M. Swager, J. Mol. Catal., A 2001, 166, 265.

[20] T. Imamoto, T. Oshiki, T. Onozawa, T. Kusomoto, K. Sato, J. Am. Chem. Soc. 1990, 112, 5244.

[21] B. Wolfe, T. Livinghouse, J. Am. Chem. Soc. 1998, 120, 5116.

[22] R. D. Baechler, K. Mislow, J. Am. Chem. Soc. 1970, 92, 3090.

[23] A. J. Canty, J. Patel, B. W. Skelton, A. H. White, J. Organomet. Chem. 2000, 599, 195.

[24] R. J. Cross, A. R. Kennedy, K. W. Muir, J. Organomet. Chem. 1995, 487, 227.

[25] L. A. van de Kuil, H. Luitjes, D. M. Grove, J. W. Zwikker, J. G. M. van der Linden, A. M. Roelofsen, L. W. Jenneskens, W. Drenth, G. van Koten, Organometallics 1994, 13, 468.

[26] P. T. Beurskens, G. Admiraal, G. Beurskens, W. P. Bosman, S. Garcia-Granda, R. O. Gould, J. M. M. Smits, C. Smykalla, DIRDIF 97 program system, 'Technical Report of the Crystallography Laboratory', University of Nijmegen, The Netherlands, 1997.

[27] G. M. Sheldrick, SHELXL-97 program for crystal-structure refinement, University of Göttingen, Germany, 1997.

[28] A. L. Spek, PLATON, multipurpose crystallographic tool, Utrecht University, The Netherlands, 2000.

[29] H. D. Flack, Acta Crystallogr., Sect. A 1983, 39, 876. 